\title{
C2C electronic business logistics analysis based on grounded theory
}

\author{
Xiao Qing Bi \& Dong Zhang \\ School of Tianjin University of technology, Tianjin 300384, China
}

\begin{abstract}
With the increase in online sales and purchasing, logistics and e-commerce market, competition between the doomed more intense. Faced with the great potential of e-commerce logistics market, many specialized logistics services for e-commerce and e-commerce logistic company self-logistics are beginning to develop rapidly. In this paper, based on this background, we analyze the history and present situation of C2C e-commerce logistics development, for enterprises to improve the level of logistics services in the actual operation, to obtain a competitive advantage to provide important reference value. This approach qualitative research grounded theory is applied to C2C electricity supplier logistics factors which influence the quality of service. Through the many factors that affect the quality of logistics services refining, relying on scientific information and practical test hypotheses, And based on the research of grounded theory .Thorough analysis on "C2C electronic business logistics service quality influence factors". Data obtained through interviews with the filter, summarize, analyze, building a new concept.
\end{abstract}

KEYWORD: E-commerce; logistics services; grounded theory

\section{INTRODUCTION}

Currently we are in an era of rapid development of Internet and computer technology, which not only changed the way of we work, but also for other aspects of our lives and have had a great impact. As the era of online shopping network a more popular way to shop, convenient features such as the rapid development of many people's lives become an indispensable part. Our e-commerce market has shown great potential for development, and the market economy in our country began to occupy a very important position (Bienstoek C C, 1997).

Faced with the great potential of e-commerce logistics market, many specialized logistics services for e-commerce and e-commerce logistics company self-logistics are beginning to develop rapidly. In this paper, grounded theory is based on the current three common logistics model: Third-party logistics model, self-built logistics model and a mixed-mode, one - third party logistics model specific analysis, this paper is based on this topic background mode of C2C e-commerce logistics and services as well as logistics and services related factors depth analysis (John R. Grout. 2000). I am hoping to give many C2C businesses in the actual operation of how to improve the level of logistics services, how in the fierce market in an invincible position in the elec- tricity supplier is eligible provided some reference value.

\section{INFLUENCING FACTORS OF C2C ELECTRICITY SUPPLIER LOGISTICS SERVICE QUALITY}

\subsection{The basic principle grounded theory approach}

The so-called grounded theory method is existing data collection, analysis and electricity inducted, so that by summary, obtained a temporary mining theory. The information collected and the daily experience hypothetical basis. Further investigate the hypothesis, draw conclusions, and established theory. It is worth noting that the proposed theoretical assumptions not occur before the researchers collected data, but the data collected by the empirical generalizations, for continuous comparison of a step by step presented to reflect the concept of research, the concept extends development and ultimately the theory.

Based on available information or phenomenon, a top-down manner thereby developed inductive grounded theory achievement (Juran J M, 1991).

While Grounded Theory and empirical evidence are inseparable, but its main feature is not empirical, but summarized the proposed new discoveries, new ideas and new concepts of organizational models as 
well as the interaction between the experience and profile. The basic procedure is as follows root Theory Figure 1:

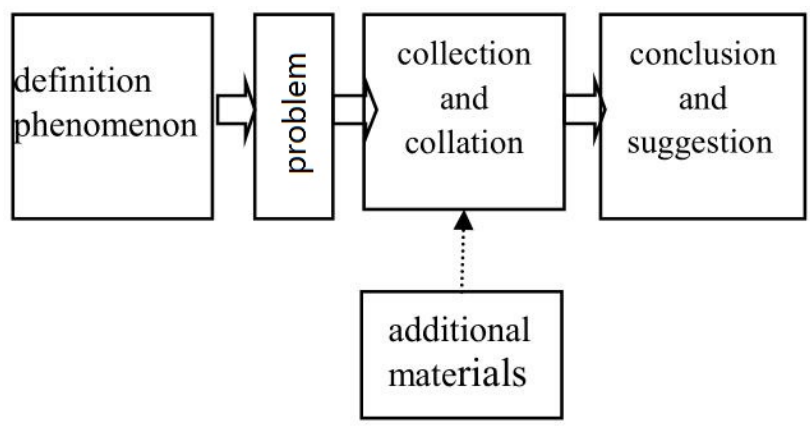

Fig. 1 Grounded Theory flowchart

\subsection{The issues raised and literature review}

Since C2C sellers dispersible, costs are low, smallscale features is its inability to build their own electricity supplier and distribution system, third-party logistics C2C sellers is undoubtedly the best choice, with the growing volume of supplier industry increased its dependence on third-party logistics deepening. Thus, although our country has a lot of thirdparty logistics to choose from, but C2C sellers still difficult to achieve control of logistics services, and there is no ability to significantly reduce logistics prices.

The electricity supplier activities in the quality of goods and logistics services together constitute the customer evaluation of the activities of this purchase, the buyer of the goods does not take the time to evaluate the quality of goods and logistics services separately evaluated, in therefore, the customer evaluation of the seller logistics services and customer satisfaction will be inseparable. Access to relevant information, in How Net the search box to enter Wan fang, VIP and other authoritative information website "third-party logistics service quality" search, access to relevant information and select information relevant to this study in-depth analysis of C2C electricity supplier logistics service quality factors analysis is the original intention of the study [3].

\subsection{Data collection and induction}

\section{Sampling process}

C2C collect affect electricity supplier logistics service quality data, it can take a variety of ways. Including questionnaires, interviews, and online survey can provide data-based study. Information derived from the theory, the resulting theory in-depth analysis, thereby forming a theoretical concept, which is rooted.

In this study, I used to interview forms for data in the theory of the research process. Thoroughly col- lected. For a study to determine the district residents, the district residents' daily lives frequent online shopping. The district residents both rich online shopping test, and by the strong level of education is highly skill. It can be said to be very suitable for the present study. Spare time, I used random sampling of interviews with residents, while taking on the part of residents by appointment telephone interview. Each collected interview data, collated by analyzing the "C2C electricity supplier logistics service quality factors data records."

Data Processing

Because of the respondents habits, personal preferences and shopping habits are different, the quality of C2C electricity supplier logistics service concerns the impact on different factors, in order to make this interview more comprehensive, more organized resistance. The respondents on the basis of work and income level classification. Classified as government agencies, students, clerks, housewives, and so on self-employed persons of the five sources of income falls (high-income), (middle-income), (lowincome) of these three levels.

Based on the principles of the theory of saturated, positioning the study selected 30 sample data. People working in different areas of the sample had a share of: Government agencies 4, 13\%; students 8, $27 \%$; the general staff $11,37 \%$; housewives 5, 17\%; self- employed people 2, 6\%. The number and proportion of income sample are: $8,27 \% ; 10,33 \% ; 12$, $40 \%$.

Openness decoding

Compilation process of open coding is as follows: firstly previously published coded identifiers in addition, behind every word, as identifier, $\mathrm{x}$ from the 1 start. Second, native coding principle was adopted to realize initial conceptualization, identifiers, y starting from 1.Then rename the preliminary concept, identifier for, Next, the initial concept rename identifier is, $\mathrm{z}$ from the 1 beginning; and finally, the concept of integration to become visible, and re-named as the identifier, $m$ starting at 1 . Through open coding, to explore the 256 phenomenon, to form 217 concepts, conceptual named 113, Category 33. Due to the large amount of data, the article only a partial list of open coding examples as shown in Table 1.

Spindle decoding

Spindle decoding is a potential relationship between the scope of the specific analysis, to generalize from open coding categories based on a variety of seemingly fragmented nature of the category, as well as the dimensions and other characteristics of effective integration, the eventual establishment of the relationship between them category with identifier, showing the relationship between categories (John T. Mentzer, 1999).

Through in further integration of the relationship category, determine on spindle encoder and spindle 
encoders are represented by identifier. As shown in Table 1:

Table 1 Spindle encoding process table

\begin{tabular}{|c|c|c|}
\hline $\begin{array}{l}\text { Main Cate- } \\
\text { gory } B_{\mathrm{n}}\end{array}$ & $\begin{array}{c}\text { Relation- } \\
\text { ship Category } \\
B_{\mathrm{nm}} \\
\end{array}$ & category $C_{\mathrm{m}}$ \\
\hline \multirow{4}{*}{$\begin{array}{l}\text { C2C elec- } \\
\text { tricity supplier } \\
\text { logistics ser- } \\
\text { vice quality } \\
\text { delivered by } \\
\text { staff attitude } \\
\text { affect the ser- } \\
\text { vice } B_{1}\end{array}$} & \multirow{2}{*}{$\begin{array}{l}\text { Service atti- } \\
\text { tude } B_{11}\end{array}$} & $\begin{array}{c}\text { Delivery per- } \\
\text { sonnel politeness } \\
C_{1}\end{array}$ \\
\hline & & $\begin{array}{c}\text { Sending per- } \\
\text { sonnel to patience } \\
C_{2}\end{array}$ \\
\hline & \multirow{2}{*}{\begin{tabular}{c}
\multicolumn{2}{c}{ Delivery } \\
distance $\quad B_{12}$
\end{tabular}} & $\begin{array}{l}\text { Deliver to the } \\
\text { hands of custom- } \\
\text { ers } C_{3}\end{array}$ \\
\hline & & $\begin{array}{l}\text { Deliver to the } \\
\text { cell door } C_{4}\end{array}$ \\
\hline \multirow{4}{*}{$\begin{array}{l}\text { C2C elec- } \\
\text { tricity supplier } \\
\text { logistics ser- } \\
\text { vice quality } \\
\text { delivered by } \\
\text { the Quality } \\
\text { ofB2 }\end{array}$} & \multirow{2}{*}{$\begin{array}{c}\text { Packaging } \\
\text { soundness } \\
B_{21}\end{array}$} & $\begin{array}{l}\text { Packaging in- } \\
\text { tact } C_{5}\end{array}$ \\
\hline & & $\begin{array}{l}\text { Packaging to } \\
\text { keep clean } C_{6}\end{array}$ \\
\hline & \multirow[b]{2}{*}{$\begin{array}{l}\text { Cargo in- } \\
\text { tegrity } B_{22}\end{array}$} & $\begin{array}{l}\text { The goods are } \\
\text { not damaged } C_{7}\end{array}$ \\
\hline & & $\begin{array}{c}\text { Goods con- } \\
\text { sistent with the } \\
\text { description Shop } \\
C_{8}\end{array}$ \\
\hline \multirow{4}{*}{$\begin{array}{l}\text { C2C elec- } \\
\text { tricity supplier } \\
\text { logistics ser- } \\
\text { vice quality is } \\
\text { affected by the } \\
\text { quality of re- } \\
\text { sponse } B_{3}\end{array}$} & \multirow[t]{2}{*}{\begin{tabular}{c}
\multicolumn{2}{c}{ Feedback } \\
Accuracy $\quad B_{31}$
\end{tabular}} & $\begin{array}{c}\text { Tracking } \\
\text { level of logis- } \\
\text { tics information } \\
C_{9}\end{array}$ \\
\hline & & $\begin{array}{rc}\text { Receipt } & \text { of } \\
\text { information } & C_{10}\end{array}$ \\
\hline & \multirow{2}{*}{$\begin{array}{l}\text { Error pro- } \\
\text { cessing rate } \\
B_{32}\end{array}$} & $\begin{array}{l}\text { Returns In- } \\
\text { formation } C_{11}\end{array}$ \\
\hline & & $\begin{array}{c}\text { Damaged ma- } \\
\text { terial handling } \\
C_{12}\end{array}$ \\
\hline \multirow{2}{*}{$\begin{array}{l}\text { C2C logis- } \\
\text { tics rate on } \\
\text { electricity } \\
\text { supplier logis- } \\
\text { tics service } \\
\text { quality by } B_{4}\end{array}$} & \multirow[b]{2}{*}{$\begin{array}{l}\text { Arrival rate } \\
\qquad B_{41}\end{array}$} & $\begin{array}{l}\text { Specified time } \\
\text { arrives } C_{13}\end{array}$ \\
\hline & & $\begin{array}{l}\text { Humane cus- } \\
\text { tomized to the } \\
\text { time } C_{14}\end{array}$ \\
\hline
\end{tabular}

Theoretical saturation test

Theoretical saturation refers to the fresh materials, research and analysis results are no longer a new code and category. It is grounded theory to stop sampling standard. After six sample code based on random sampling inspection, through the analysis found that no new category, according with "C2C the electronic of business logistics service quality factors on affect" Through the inspection that the theory reached in saturation.

\section{CONCLUSION}

With the coming of information age, we enter the Internet age. Online shopping is gradually rise has been accepted by more and more people. With the popularity of online shopping online shopping problems also emerge slow, the customer is more and more strictly with timely delivery time. On delivery of precious and fragile object requires better logistics service quality.

\section{REFERENES}

Bienstoek C C, 1997, Measuring Physical Distribution Service Quality. Journal of the Academy Marketing Science, 25(4): 31-44

John R. Grout. 2000. Safe guarding Supply Relationship [J].ProductionEconomics,11-14.

Juran J M, 1991, Gryna FM and Cpk Statistics Should Be Discontinued [J]. Quality Progress,24(3):8.

John T. Mentzer, Daniel J. Flint, and John L. Kent,1999, Developing a Logistics Service Quality Scale [J]. Journal of Business Logistics, 20(1): 9-32.

Mentzer J T, Gomes R, Krapfel RE. 1989, Physical distribution service: a fundamental marketing concept [J]. Journal of the Academy Marketing Science, 17(4): 53-62.

Woo Y, Hsu S L, Wu S. 2012, An integrated inventory model of a single vendor and multiple buyers with ordering cost reduction [J]. International Journal of Production Economies, 203-215 